\title{
SOSIOLIUM $\quad$ SOSIOLIUM \\ Efektivitas Model Pembelajaran E-Learning Dengan Media Kahoot Terhadap Kemampuan Analisis Peserta Didik Pada Mata Pelajaran IPS Kelas VII SMP Islam Al Azhar 29 Semarang
}

\section{Fika Puspita Anggraeni, Asep Ginanjar}

Social Science Education Department, Faculty of Social Science, Universitas Negeri Semarang, Indonesia

\section{Info Artikel}

Sejarah Artikel:

Disubmit:Mei 2020

Direvisi: Juni 2020

Diterima:Juli 2020

\section{Keywords:}

Effectiveness; $\boldsymbol{E}$ -

learning; Analysis

Skills; Social Science

Learning

\begin{abstract}
Abstrak
Pada era global menuntut dunia pendidikan untuk selalu dan senantiasa menyesuaikan perkembangan teknologi terhadap usaha dalam peningkatan mutu pendidikan, terutama penyesuaian penggunaan teknologi informasi. Tujuan penelitian adalah (1) Mengetahui bagaimanakah penerapan model pembelajaran e-learning guna menunjang kemampuan analisis peserta didik, (2) Mengetahui bagaimanakah efektivitas model belajar e-learning berbasis kahoot dalam pembelajaran IPS, (3) Mengetahui apa saja kendala yang dialami saat pengaplikasian model pembelajaran e-learning berbasis kahoot. Metode yang digunakan dalam penelitian ini yaitu kuantitatif. Penelitian ini merupakan penelitian Eksperimen Quasi menggunakan Nonequivalent Control Group Design. Hasil dari penelitian ini adalah: (1) guru mampu melakukan langkah-langkah pembelajaran dengan baik(2) Analisis kemampuan guru sesuai dengan rencana pembelajaran. (3) Aktivitas belajar peserta didik tergolong sedang, (4) Hasil belajar peserta didik jika dilihat $67 \%$ siswa kelas VII A yang tuntas KKM, hanya $13 \%$ siswa kelas VII B yang tuntas KKM sehingga dapat dikatakan efektif. (5) Dapat diketahui bahwa siswa merespon baik terhadap pembelajaran Sedangkan untuk variabel ketrampilan, dapat diketahui memiliki ketrampilan baik, hasil tersebut dapat dikatakan efektif. (6) Terdapat kendala yaitu pada hardware yang tersedia, kendala pada pihak peserta didik sendiri yaitu terdapat beberapa peserta didik yang memiliki gejala rabun jauh. Kesimpulan dari penelitian ini adalah model pembelajaran dapat dikatakan efektif.
\end{abstract}

Abstract

In the global era demanded the world of education to always and constantly adjust technological developments to efforts in improving the quality of education, especially adjustments to the use of information technology. The research objectives are (1) Knowing how the application of e-learning learning models to support students' analytical skills, (2) Knowing how the effectiveness of kahoot-based e-learning learning models in social studies learning, (3) Knowing what obstacles are experienced when applying the model Kahoot-based e-learning learning. The method used in this research is quantitative. This research is a Quasi Experiment research using Nonequivalent Control Group Design. The results of this study are: (1) teachers are able to carry out the steps of learning well (2) Analysis of the ability of teachers in accordance with the learning plan. (3) Student learning activities are classified as moderate, (4) Student learning outcomes if seen $67 \%$ of students of Class VII A who complete KKM, only $13 \%$ of Class VII B students who complete KKM so that it can be said to be effective. (5) It can be seen that students respond well to learning. As for the skills variable, it can be known to have good skills, the results can be said to be effective. (6) There are obstacles, namely the available hardware, the constraints on the part of the students themselves, namely there are some students who have symptoms of nearsightedness. The conclusion from this study is that the learning model can be said to be effective.

(C) 2020 Universitas Negeri Semarang

\footnotetext{
Alamat korespondensi:

Gedung C1 Lantai 1 FIS Unnes

Kampus Sekaran, Gunungpati, Semarang, 50229

E-mail: asep.ginanjar@mail.unnes.ac.id
}

E-ISSN 2685-4929 


\section{PENDAHULUAN}

Inovasi baru dalam upaya mengajar mata pelajaran ips sangat diperlukan, terutama dalam kurikulum 2013 dimana semakin kompleksnya tuntutan belajar terhadap peserta didik yang terkadang membuat pola pikir peserta didik menjadi stagnan. Menurut martoella (1987) dalam jurnal pendidikan purnomo, dkk (2016: 14) memberikan pernyataan bahwa pembelajaran pendidikan ips lebih berfokus terhadap "pendidikan" dibandingkan dengan "transfer proses", hal tersebut disebabkan karena peserta didik diharapkan memperoleh pemahaman terhadap sejumlah konsep dan mengembangkan serta melatih sikap, nilai, norma, dan keterampilannya berdasarkan konsep yang telah dimilikinya. Dengan demikian pembelajaran pendidikan ips harus lebih menyenangkan juga lebih efisien guna mendapatkan informasi yang dibutuhkan terutama dalam aspek sosial dan berhubungan dengan mata pelajaran yang dipelajari yaitu mata pelajaran ilmu pengetahuan sosial.

Menurut Sudarma dalam (Warsita, 2008: 136) teknologi informasi dan internet sudah merasuk dalam kehidupan kita sehari-hari, termasuk dalam bidang pendidikan. Maksudnya saat ini internet bukan lagi menjadi barang "Lux", bahkan sudah menjadi bagian yang tidak terpisahkan dalam aktivitas kita sehari-hari baik sebagai pelajar, mahasiswa, maupun bagi para pembisnis. Pelajar dan mahasiswa memanfaatkan internet sebagai sumber belajar (learning resaurces). Elearning berfokus pada student centered dimana peserta didik dipermudah dalam memahami dan mengakses materi, model ini sangat efisien dari segi waktu, tenaga, dan tempat karena tidak sebatas dilakukan diruangan kelas namun juga dapat dilakukan di dalam rumah. E-learning sendiri memiliki ciri khas dalam pelaksanaannya yaitu dilengkapi dengan media pembelajaran online, yang tersambung kedalam jaringan internet.

Adanya penggunaan jaringan internet dan aplikasi virtual akan menciptakan suatu model pembelajaran yang inovatif dan aktif, yang kemudian akan menstimulus para peserta didik untuk lebih memahami dan mendalami materi yang disampaikan oleh pengajar, tak hanya itu adanya keterlibatan jaringan internet membuat peserta didik leluasa dalam mempelajari dan mengakses materi melalui sistem daring yang kemudian memungkinkan untuk mencapai pembelajaran yang efektif dan efisien dalam proses proses pembelajaran (KBM). Penggunaan jaringan internet dalam proses pembelajaran dan juga penggunaan aplikasi virtual dalam pembelajaran tersebut yang kemudian dinamakan model pembelajaran e-learning.

Dalam kegiatan pengamatan dan wawancara dengan guru IPS kelas VII yang dilakukan oleh peneliti di SMP Islam Al Azhar 29 Semarang penggunaan media pembelajaran digital sudah berjalan, namun pada kenyatannya cara penyampaian dan model pembelajaran yang digunakan masih didominasi model pembelajaran ceramah dan strategi berbasis masalah juga masih kurang efektif diberikan pada peserta didik hal tersebut menyebabkan peserta didik menjadi kurang konsentrasi saat memahami materi dalam mata pelajaran IPS di kelas, sehingga kegiatan belajar di kelas relatif kurang kondusif, penggunaan gawai juga cenderung disalah gunakan karena kurangnya konsetrasi dalam menerima materi, serta cara berfikir peserta didikpun menjadi terbatas kepada apa yang disampaikan oleh pengajar saja.

Kegiatan mengajar Menurut Daryanto dan Muljo dalam Model Pembelajaran Inovatif (2012: 1) mengajar adalah membimbing kegiatan belajar peserta didik sehingga peserta didik 
tersebut mau belajar. Dengan demikian, aktivitas peserta didik sangat diperlukan dalam proses pembelajaran sehingga peserta didiklah yang seharusnya banyak aktif, sebab peserta didik sebagai subjek didik sekaligus yang merencanakan dan ia sendiri yang melaksanakan belajar.

Menurut Daryanto (2011: 149) $e$ learning adalah sistem pembelajaran yang memanfaatkan media elektronik sebagai alat untuk membantu kegiatan pembelajaran. Sebagian besar berasumsi bahwa elektronik yang dimaksud disini lebih diarahkan pada penggunaan teknologi komputer dan internet. Melalui komputer siswa dapat belajar secara individual, baik secara terprogram maupun tidak terprogram. Secara tidak terprogram, siswa dapat mengakses berbagai bahan belajar dan informasi dengan menggunakan fasilitas di internet (search enggine). Secara bebas, siswa dapat mencari bahan informai sesuai dengan minat masing-masing tanpa adanya intervensi dari siapapun.

Daryanto (2011: 162) internet dapat digunakan secara terprogram, salah satunya dengan program e-learning. Pada program ini sekolah atau pihak penyelenggara menyediakan sebuah situs/web e-learning yang menyediakan bahan ajar secara lengkap baik bersifat interaktif maupun non interaktif. Di Indonesia e-learning bukan alat pembelajaran utama meainkan sebagai bahan dan pelengkap dari pembelajaran konvensional.

Pembelajaran dengan kontrol guru dikelas masih tetap dominan, siswa belum secara totalitas menggunakan internet sebagai suplemen dan belum sebagai komplemen atau PBM konvensional. Menurut Boettcher dalam Daryanto (2011:

150) dalam e-learning penggunaan internet diharapkan mampu memberikan dukungan bagi terselenggaranya proses komunikasi interaktif antara siswa dengan guru. Dalam e-learning kondisi yang perlu didukung dengan internet berkaitan dengan strategi pembelajaran yang akan dikembangkan, yaitu sebagai kegiatan komunikasi yang dilakukan untuk mengajak siswa mengerjakan tugas-tugas dan membantu siswa dalam memperoleh pengetahuan yang dibutuhkan dalam rangka mengerjakan tugastugas tersebut.

Penggunaan e-learning untuk keperluan pembelajaran yang semakin meluas terutama di negara-negara maju merupakan fakta yang menunjukan bahwa dengan media berbasis internet memungkinkan terselenggara proses pembelajaran yang lebih efektif. Hal itu terjadi karena dengan sifat dan karakteristik internet yang cukup khas, sehingga diharapkan bisa digunakan sebagai media pembelajaran sebagaimana media yang telah dipergunakan sebelumnya seperti radio, TV, CD-ROM interaktif, dan lain-lain. Menurut Purbo dalam Bambang (2008: 144) diantara keseluruhan fasilitas internet terdapat lima aplikasi standar internet yang dapat digunakan untuk keperluan pembelajaran, yaitu E-mail, Mailing List, Newsgroup, File Transfer Protocol, World Wide Web. Namun dalam hal ini peneliti menggunakan media virtal lainnya yaitu media Kahoot.

Menurut Cahya (2018: 43) kahoot adalah suatu game interaktif berbasis pendidikan yang didalamnya terdapat beberapa ikon untuk dikembangkan. Salah satunya yaitu ikon kuis dimana pengguna dapat menggunakan kahoot untuk suatu pembelajaran sehingga pembelajaran menjadi menarik dan tidak membosankan. Kahoot ini dapat berjalan menggunakan koneksi internet. Kahoot memiliki empat fitur yaitu game, kuis, diskusi, dan survei, kahoot sediri dapat digunakan dalam proses pembelajaran seperti pre-test, post- test, latihan soal, pengayaan, dan perbaikan. Dalam aplikasi ini jawaban yang keluar akan diwakili oleh warna- warna. Mengakses media digital kahoot 
sendiri terdapat dua cara yaitu bagi admin dapat diakses melalui

https://getkahoot.com sedangkan bagi peserta dapat mengakses kahoot melalui kahoot.it (https://create.kahoot.it/).

Tujuan penggunaan model pembelajaran e-learning sendiri bertujuan guna meningkatkan kemampuan analisis. Menurut Rony, dkk (2009) dalam artikel ilmiah Marini (2014: 4) mengungkapkan analisis adalah dasar dari sebuah pemikiran urut dan sistematis. Lewat berpikir analisis kita dapat menguraikan beberapa masalah ibarat mengurai benang kusut. Adapun beberapa ciri-ciri analisis menurut Rony, dkk (2009) dalam Marini (2014: 4) sebagai berikut: (1) berfikir

sistematis, (2) disiplin tinggi, (3) menghargai fakta yang disampaikan secara logis, (4) menyukai hal-hal yang terorganisir, (5) teliti dan fokus pada detail masalah, (6) cenderung kaku, (7) lama dalam mengambil keputusan. Sedangkan menurut Ahmaddi dalam Psikologi Umum (2009: 83) peserta didik juga dituntut untuk dapat berfikir secara analisis dimana peserta didik harus dapat mengkolaborasikan keterampilan dengan pemikiran rasional sehingga timbulah analisis yang kemudian akan membuat peserta didik atau peserta didik memahami apa yang harus dilakukan atau apa yang harus difikirkan dalam menghadapi suatu masalah pada materi yang disajikan oleh pengajar.

Dalam kamus besar bahasa Indonesia (2007) analisis adalah penyelidikan terhadap suatu peristiwa (karangan, perbuatan, dan sebagainya) untuk mengetahui keadaan yang sebenarnya (sebab musabab, duduk perkaranya, dan sebagainya). Analisis merupakan komponen yang membahas tujuan pembelajaran berkenaan dengan proses mental yang berawal dari tingkat pengetahuan sampai ke tingkat yang lebih tinnggi yakni evaluasi. Menurut Bloom (1956) kawasan kognitif ini terdiri dari 6 tingkatan yang secara hierarkis berurut dari yang paling rendah (pengetahuan) sampai ke yang paling tinggi (evaluasi) dan dapat dijelaskan sebagai berikut:

1 Tingkat Pengetahuan

(Knowledge) Pengetahuan disini diartikan sebagai kemampuan seseorang dalam menghafal atau mengingat kembali atau mengulang kembali pengetahuan yang pernah diterimanya; (2) Tingkat Pemahaman

\section{(Comprehension)}

Pemahaman disini diartikan sebagai kemampuan seseorang dalam mengartikan, menafsirkan, menerjemahkan, atau menyatakan sesuatu dengan caranya sendiri tentang pengetahuan yang pernah diterimanya; (3) Tingkat Penerapan (Application) Penerapan disini diartikan sebagai kemampuan seseorang dalam

menggunakan pengetahuan dalam memecahkan berbagai masalah dalam kehidupan sehari-hari; (4) Tingkat Analisis (Analysis) Analisis disini diartikan sebagai kemampuan seseorang dalam menguraikan suatu situasi atau keadaan tertentu atau pengetahuan yang telah ia dapatkan kedalam unsur-unsur atau komponen-komponen pembentuknya;

(5) Tingkat Sintesis (Synthesis) Sintesis disini diartikan sebagai kemampuan seseorang dalam mengaitkan dan menyatukan berbagai elemen dan unsur pengetahuan yang ada sehingga terbentuk pola baru yang lebih menyeluruh; (6) Tingkat Evaluasi (Evaluation) Evaluasi disini diartikan sebagai kemampuan seseorang dalam membuat perkiraan atau keputusan yang tepat berdasarkan kriteria atau pengetahuan yang dimilikinya. Menurut Wowo dalam buku Taksonomi Kognitif (2014: 53) analisis menekankan pada pendeteksian hubunganhubungan setiap bagian yang tersusun secara sistematis. Menganalisis sendiri merupakan keterampilan dimana seorang individu memecahkan suatu masalah menjadi beberapa bagian kemudian 
mencoba untuk mengintegrasikan dan menghubungkan satu sama lain agar menjadi sebuah tujuan atau kesimpulan. Dalam hal ini peserta didik diharapkan dapat mengembangkan kemampuan analisis dengan menghubungkan semua informasi atau gagasan yang berbeda menjadi sebuah kesatuan berdsarkan konsep, prinsip, dan standar pembelajaran yang telah diterima pengajar, dengan begitu peserta didik dapat terbisa dengan keterampilan menganalisis dan dapat mengembangkan kemampuan analisis didalam situasi baru secara kreatif.

Hal tersebut yang kemudian akan diterapkan pada mata pelajaran Ilmu Pengetahuan Sosial yang ada di sekolah, Ilmu Pengetahuan Sosial adalah penyederhanaan dan adaptasi dari disiplin ilmu-ilmu sosial dan humaniora, serta kegiatan dasar manusia yang disajikan dan diorganisasikan secara ilmiah secara psikologis/paedagogis, untuk tujuan pendidikan (Soemantri 2009: 92). IPS sebagai salah satu kajian ilmu yang merupakan mata pelajaran pokok dan wajib bagi tingkat pendidikan SMP, sebagaimana dinyatakan dalam undang- undang No. 20 Tahun 2003 mengenai sistem pendidikan Nasional Pasal 39, IPS merupakan salah satu mata pelajaran yang diberikan dari SD/MI/SDLB sampai SMP/MTS/SMPLB yang mengkaji seperangkat peristiwa, fakta, konsep, dan generalisasi yang berkaitan dengan isu sosial.

IPS menurut Wahab (2009: 17-18) merupakan suatu kajian bidang gejala dan masalah sosial. Proses pembelajaran IPS sendiri dilakukan secara berkesinambungan dan bertahap sesuai dengan kebutuhan dan tingkat usia peserta didik, pada hakikatnya Ilmu Pengetahuan Sosial merupakan panduan mata pelajaran yang berbasis sosial, di SMP sendiri IPS merupakan gambaran mata pelajaran yang terdiri dari geografi, sejarah, ekonomi, sosiologi, dan atropologi (tersirat).
IPS menurut Hidayati, dkk (2008: 31) merupakan integrasi dari ilmu-ilmu sosial, kajian IPS adalah manusia dan lingkungan. Manusia sebagai makhluk sosial selalu hidup bersama dengan manusia lainnya. Dalam kehidupannya manusia harus menghadapi tantangan yang berasal dari lingkungannya.

Menurut Gross (1978) dalam Jurnal Pendidikan Purnomo,dkk (2016: 14) Ilmu Pengetahuan Sosial berbeda dengan disiplin ilmu yang monodisiplin. IPS memiliki keterpaduan antar disiplin ilmu sosial. Geografi memberikan wawasan yang berkenaan dengan wilayah-wilayah, sejarah memberikan wawasan tentang pariwisata-pariwisata yang terjadi pada masa lampau, ekonomi memberikan wawasan tentang berbagai macam kebutuhan manusia, dan sosiologi, antropologi memberikan wawasan yang berkenaan dengan nilai-nilai, kepercayaan, struktur sosial, lalu ilmu politik lebih kepada mengkaji hubungan antara warga dengan warga negaranya, dan psikologi membahas mengenai kondisi kejiwaan seseorang atau manusia. Sosiologi dan psikologi sosial merupakan ilmu-ilmu tentang perilaku seperti konsep peran, kelompok, institusi, proses interaksi dan kontrol sosial. Secara intensif konsep- konsep seperti ini digunakan ilmu-ilmu sosial dan studi-studi sosial.

Tujuan pembelajaran IPS adalah untuk memberikan pengetahuan dan bekal bagi peserta didik, tak hanya itu Ilmu Pengetahuan Sosial juga berperan penting untuk memberikan pendidikan moral bagi peserta didik yang akan menjadi generasi penerus bangsa nantinya, dari segi pembelajaran yang mencakup segala aspek kehidupan sosial, yang kemudian menjadi bahan pembelajaran dan disampaikan kepada peserta didik, sehingga peserta didik dapat melalui kehidupan sosialnya dengan baik serta dapat memilahmilah mana bagian yang baik dan bagian yang buruk dalam kehidupan sosialnya. Selain 
itu tujuan pembelajaran IPS adalah untuk memberi bekal kemampuan dasar kepada peserta didik untuk mengembangkan diri sesuai dengan bakat, minat, dan kemampuan dari lingkungannya serta berbagai bekal bagi peserta didik untuk melanjutkan kejenjang pendidikan yang lebih tinggi (Etin Solihatin dan Raharjo, 2007: 15).

Berdasarkan keterangan diatas peneliti tertarik untuk meneliti tentang efektivitas model pembelajaran e-learning dengan media kahoot terhadap kemampuan analisis peserta didik pada mata pelajaran IPS kelas VII SMP Islam Al Azhar 29 Semarang. Alasan peneliti melakukan penelitian ini adalah guna memperkenalkan model pembelajaran $e$ learning dan ingin melihat apakah $e$-learning dilengkapi kahoot efektif untuk mestimulus kemampuan analisis dalam mata pelajaran IPS di SMP Islam Al Azhar 29 Semarang. Penelitian yang akan dilaksanakan berjudul "Efektivitas Model Pembelajaran E-Learning Dengan Media Kahoot Terhadap Kemampuan Analisis Peserta Didik Pada Mata Pelajaran IPS Kelas VII SMP Islam Al Azhar 29 Semarang"

Rumusan masalah dalam penelitian ini yaitu, (1) Bagaimanakah penerapan model pembelajaran e-learning guna menunjang kemampuan analisis peserta didik pada mata pelajaran IPS kelas VII SMP Islam Al Azhar 29 Semarang?; (2) Bagaimanakah efektivitas model pembelajaran e-learning dalam pembelajaran IPS terhadap kemampuan analisis peserta didik di SMP Islam Al Azhar 29 Semarang?; (3) Apa saja kendala dalam pengaplikasian model pembelajaran e-learning pada pembelajaran IPS di kelas VII SMP Islam Al Azhar 29 Semarang?

Tujuan penelitian ini yaitu, (1) Mengetahui bagaimanakah penerapan model pembelajaran e-learning guna menunjang kemampuan analisis peserta didik pada mata pelajaran IPS kelas VII
SMP Islam Al Azhar 29 Semarang; (2) Mengetahui bagaimanakah efektivitas model belajar e-learning berbasis kahoot dalam pembelajaran IPS terhadap kemampuan analisis peserta didik di SMP Islam Al Azhar 29 Semarang; (3) Mengetahui apa saja kendala yang dialami saat pengaplikasian model pembelajaran e- learning berbasis kahoot pada pembelajaran IPS di kelas VII SMP Islam Al Azhar 29 Semarang.

Hasil penelitian ini dapat memberikan sumbangan pemikiran bagi guru IPS sebagai Penggunaan model pembelajaran e-learning yang sesuai dengan materi pembelajaran, serta kebutuhan peserta didik sangat diperlukan dalam proses pembelajaran di kelas agar mampu mendorong kemampuan analisis peserta didik sehingga mampu meningkatkan hasil belajar peserta didik. Penggunaan variasi dalam model pembelajaran e-learning juga diperlukan seperti games atau media penunjang berbasis virtual lainnya agar peserta didik lebih tertarik pada pelajaran IPS dan berpengaruh terhadap kemampuan analisis peserta didik dan hasil belajar peserta didik. Bagi peneliti lain model pembelajaran e-learning dapat dikembangkan lebih optimal lagi mengingat kemajuan zaman yang semakin canggih serta era digital yang mengglobal dapat menjadi alternatif model yang kemudian dipadukan dengan variasi media virtual dalam pembelajaran IPS di SMP.

\section{METODE PENELITIAN}

Penelitian kali ini menggunakan metode penelitian kuantitatif, Desain yang akan digunakan oleh peneliti kali ini yaitu dengan menggunakan desain eksperimen. Penelitian eksperimen dapat diartikan sebagai metode penelitian yang digunakan untuk mencari pengaruh perlakuan tertentu terhadap yang lain dalam kondisi yang terkendalikan. Ada beberapa bentuk eksperimen yaitu: (1) Pre Experimental 
Design (eksperimen yang belum baik), (2) True Experimental Design (eksperimen yang betulbetul), (3) Factorial Design (modifikasi dari true experimental), dan

(4) Quasi Experimental Design (eksperimen semu) (Sugiyono 2013: 107- 109).

Desain penelitian yang dilakukan oleh peneliti kali ini adalah menggunakan eksperimen (quasi experimental design) dengan pola Nonequivalent Control Group Design. Dalam desain ini terdapat dua kelas yang dipilih secara tidak random, kemudian diberi pretest dan posttest dan hanya kelas eksperimen yang mendapat perlakuan, sedangkan kelas kontrol tidak diberi perlakuan tetapi melaksanakan pembelajaran seperti biasa yaitu menerima materi dari guru secara konvensional (Sugiyono 2013: 116).

Populasi yang digunakan oleh peneliti, yaitu kesuluruhan peserta didik sebanyak 90 orang, Dalam penelitian ini teknik pengambilan sampel yang digunakan adalah sampel purposive sampling. Teknik ini digunakan dengan pertimbangan tertentu dan digunakan apabila sasaran sampel yang diteliti telah memiliki karakteristik tertentu sehingga memenuhi tujuan dari penelitian yang akan diterapkan (Sugiyono, 2012:124). Berdasarkan observasi yang dilakukan peneliti menggunakan sampel kelas VII Al-Fatihah sebagai kelas eksperimen dan kelas VII AlBaqarah sebagai kelas kontrol daftar nama sempel. Dengan pertimbangan bahwa kedua kelas sama sama belum mendapatkan model pembelajaran e-learning, dan bukan merupakan kelas uji coba.

Berikut merupakan variabel dari penelitian ini, variabel Independen: efektivitas model pembelajaran $e$ - learning, variabel dependen: kemampuan analisis peserta didik pada mata pelajaran IPS kelas VII SMP Islam Al Azhar 29 Semarang. Variabel ini dibagi menjadi beberapa sub variabel seperti berikut: (1)
Kemampuan guru dalam mengelola pembelajaran; (2) Ketercapaian aktivitas belajar dalam kegiatan pembelajaran IPS menggunakan model pembelajaran $e$ - learning; (3) Respon peserta didik menerima pembelajaran; (4) Hasil belajar peserta didik.

Pada penelitian ini metode pengumpulan data yang digunakan oleh peneliti adalah sebagai berikut: (1) Observasi, Metode observasi yaitu pengamatan serta pencatatan terhadap gejala yang tampak pada objek penelitian. Maka dalam penelitian ini peneliti menggunakan pengamatan langsung terhadap lokasi penelitian SMP Islam Al Azhar 29 Semarang khususnya kelas VII, keadaan guru, peserta didik, sarana prasarana belajar, serta letak geografisnya;

(2) Tes, Pengumpulan data menggunakan tes seperti lembar pretes dan posttest digunakan untuk mengetahui kondisi efektivitas penerapan model pembelajaran e-learning terhadap kemampuan analisis peserta didik kelas VII SMP Islam Al Azhar 29 Semarang;

(3) Angket, Pengumpulan data menggunakan angket yaitu dengan mengisi angket yang didalamnya sudah terdapat beberapa pertanyaan yang disediakan oleh pihak peneliti dimana pertanyaan tersebut berguna untuk mencari tau tujuan peneliti; (4) Dokumentasi, wetode dokumentasi digunakan untuk mendapatkan data mengenai daftar nama peserta didik yang menjadi populasi dan sampel serta mengenai kegiatan peserta didik di dalam kelas.. Selain itu, metode ini juga digunakan untuk mengumpulkan data tentang kondisi dan gambaran umum sekolah; (5) Wawancara, wawancara dilakukan kepada pihak guru IPS untuk mengatahui kendala yang dialami guru saat menerapkan model pembelajaran e- learning pada kelas eksperimen.

Dalam pengujian validitas pada peelitian kali ini peneliti menggunakan uji 
validitas logis dan uji validitas empiris dimana uji validitas logis ini dilakukan dengan membuat instrumen yang kemudian dikonsultasikan dengan ahli seperti dosen pembimbing dan guru pendamping, sedangkan uji validitas empiris dilakukan setelah pengambilan data sampel sejumlah 29 peserta didik kelas 7 Ali Imran SMP Islam Al Azhar 29 Semarang. Menurut Sugiyono (2012:173) instrumen yang dikatakan valid berarti alat ukur yang digunakan untuk mendapatkan data (mengukur) itu valid. Valid berarti instrumen tersebut dapat digunakan untuk mengukur apa yang seharusnya diukur. Instrumen yang tidak teruji validitas dan reliabilitasnya bila digunakan untuk penelitian akan menghasilkan data yang sulit dipercaya kebenarannya. Sedangkan dalam uji reliabilitas peneliti menggunakan sampel sebanyak 29 anak di SMP Islam Al Azhar 29 Semarang, kemudian dihitung menggunakan bantuan program $I B M$ SPSS 20.0 for windows dengan analisis uji statistik Cronbach Alpha.

Sedangkan tingkat kesukaran soal pada instrumen dapat diketahui bahwa dari 25 butir soal yang valid terdapat 7 butir soal dalam kategori mudah, 13 butir soal dalam kategori sedang, dan 5 butir soal dalam kategori sukar. Dari hasil ini dapat ditarik kesimpulan bahwa soal ini baik digunakan sebagai salah satu instrumen dalam penelitian yang diajukan. Daya beda yang terdapat pada perhitungan uji beda melalui Ms. Exel 2010 diketahui bahwa dari 25 butir soal yang valid terdapat 10 butir soal dengan daya pembeda baik dan 15 butir soal dengan daya pembeda cukup.

Teknik analisis data digunakan untuk mengolah data yang telah diperoleh, mulai dari awal sampai dengan data akhir. Teknik analisis data yang digunakan untuk membuktikan hipotesis adalah teknik korelasi untuk menentukan besarnya hubungan antara dua variabel. Instrumen penelitian adalah suatu alat yang digunakan mengukur fenomena alam maupun sosial yang diamati. Secara spesifik semua fenomena ini disebut variabel penelitian (Sugiyono, 2012:148).

\section{HASIL DAN PEMBAHASAN}

Efektivitas adalah terlaksananya kegiatan dengan baik, teratur, bersih, rapih, sesuai dengan aturan dan mengandung unsur seni (Supardi 2013: 164). Efektivitas adalah usaha untuk mencapai sasaran yang di tetapkan sesuai dengan yang dibutuhkan dan juga sesuai dengan rencana, melalui aktivitas tertentu baik secara fisik maupun non-fisik untuk memperoleh hasil yang maksimal. . Sedangkan menurut Sinambela dalam Jurnal Generasi Kampus (2008: 78) efektivitas dapat terlaksana apabila memenuhi empat indikator diantaranya (1) ketercapaian ketuntasan belajar, (2) ketercapaian keefektivitasan aktivitas peserta didik, yaitu pencapaian waktu ideal yang digunakan peserta didik untuk melakukan setiap kegiatan yang termuat dalam rencana pembelajaran, (3) ketercapaian efektivitas guru dalam menyampaikan pembelajaran, serta (4) respon peserta didik terhadap pembelajaran yang positif.

Kegiatan mengajar Menurut Daryanto dan Muljo dalam Model Pembelajaran Inovatif (2012: 1) mengajar adalah membimbing kegiatan belajar peserta didik sehingga peserta didik tersebut mau belajar. Dengan demikian, aktivitas peserta didik sangat diperlukan dalam proses pembelajaran sehingga peserta didiklah yang seharusnya banyak aktif, sebab peserta didik sebagai subjek didik sekaligus yang merencanakan dan ia sendiri yang melaksanakan belajar.

\section{Penerapan Model Pembeajaran E- learning}

Peneliti melakukan pengamatan ketika treatment berlangsung di kelas eksperimen, sebelum treatment peneliti 
menyiapkan beberapa perangkat pembelajaran seperti silabus, RPP, dan juga lembar pretestpostets pada guna mengukur perbedaan hasil belajar peserta didik, perangkat pembelajaran mampu diamatipada lampiran. Selain itu langkah- langkah yang mampu diamati dalam kegiatan di kelas eksperimen kemudian peneliti mencatat aspek-aspek yang mampu diamati.

Melalui hasil pengamatan yang dilakukan oleh peneliti dapat ditarik beberapa hasil yaitu guru mampu menerapkan model pembelajaran $e$ - learning dengan baik, guru mampu melakukan langkah pembelajaran dengan menggunakan komposisi 50/50 dari alokasi waktu yang diberikan dimana 50\% untuk kegiatan pembelajaran tatap mukan, dan $50 \%$ dilakukan pembelajaran daring. Dalam kegiatan penerapan model pembelajaran bended learning guru juga sudah mampu menempatkan skenario pembelajaran dengan baik, dari mulai menyiapkan peralatan yang terdiri dari hardware dan software, materi pembelajaran yaitu materi lembaga sosial, memanfaatkan alokasi waktu, menyiapkan sumber dan media belajar, serta mengkondisikan kelas.

Efektivitas Model Pembelajaran E- learning Dalam Pembelajaran IPS Terhadap Kemampuan analisis

\section{Kemampuan Guru Dalam Mengelola Pembelajaran}

Kemampuan dalam mengelola pembelajaran ini yang diamati guru IPS kelas VII SMP Islam Al Azhar 29 Semarang, skor penilaian dalam mengelola pembelajaran terbagi menjadi 4 kriteria yaitu: rendah, cukup, tinggi, dan sangat tinggi. Masing-masing kriteria memiliki skor mulai dari skor rendah (1), skor cukup (2), skor tinggi (3), dan skor sangat tinggi (4). Adapun aspek penilaian mencakup empat indikator yang kemudian dibagi kembali menjadi 20 sub-indikator.
Berdasarkan penilaian dari guru IPS kelas VII hasil penjabaranya adalah sebagai berikut: indikator pertama yang terdiri dari tiga sub indikator mendapatkan skor 11 kemudian indikator kedua yaitu kegiatan inti pembelajaran dibagi menjadi 14 subindikator dan jumlah skornya juga mendapatkan 43, indikator ketiga merupakan kegiatan penutup dimana kegiatan penutup duibagi menjadi 2 sub indikator hasilnya mendapatkan skor 7, selanjutnya indikator ke-empat yaitu aokasi waktu mendapatkan jumlah skor yaitu 4 . Berdasarkan penjumlahan dari ke- empat indikator didapatkan hasil akhir atau skor total 64 skor, maka termasuk dalam kategori tinggi, yang mempunyai arti bahwa sudah terlaksana sesuai dengan rencana pembelajaran menggunakan model pembelajaran e-learning.

\section{Aktivitas Peserta Didik}

Aspek - aspek yang tercantum untuk dilakukan penilaian yaitu terdiri dari

17 aspek, skor maksimal untuk aspek tersebut yaitu 4, skor tersebut masuk kedalam kriteria sangat tinggi, skor 3 masuk dalam kriteria tinggi, skor 2 yaitu cukup, sedangkan skor 1 mempunyai arti rendah. Setelah mendapatkan data dari hasil penilaian aktivitas belajar peserta didik tersebut maka data tersebut diakumulasikan dan dibentuk interval nilai sesuai dengan hasil yang didapatkan serta kriteria berdasarkan interval tersebut yaitu mulai dari 19 - 28 mempunyai arti sangat rendah, 29 - 38 rendah, 39 - 48 sedang, 49

- 58 tinggi dan 58 - 68 yaitu sangat tinggi. Proses penilaian aktivitas belajar peserta didik diamati oleh guru mata pelajaran IPS serta diberikan nilai sesuai dengan aspek yang telah tercantum. Berdasarkan data hasil aktivitas peserta didik yang paling banyak menjawab dengan skor 4 yaitu terdapat pada bagian listening activities sebesar $60 \%$ yaitu 18 orang.

Jadi apabila jumlah rata-rata aktivitas peserta didik mendapatkan nilai $39-48$ mempunyai arti bahwa aktivitas 
peserta didik dalam mengikuti proses pembelajaran IPS dengan menggunakan model pembelajaran e-learning yang telah berlangsung dalam kategori sedang dan dapat dikatakan cukup efektif.

\section{Hasil Belajar}

Pelaksanaan pretest yaitu peserta didik dari kelas eksperimen yaitu kelas VII A mendapatkan nilai tertinggi yaitu 92 sebanyak 1 peserta didik, nilai terendah yaitu 32 sebanyak 1 peserta didik. sedangkan pretest pada kelas kontrol VII B mendapat nilai tertinggi 88 sebanyak 1 orang peserta didik, dan nilai terendah 28 sebanyak 1 orang peserta didik. Pada pelaksanaan pretest ini jumlah peserta didik yang berhasil mencapai batas tuntas mata pelajaran IPS atau KKM hanya berjumlah 5 orang dari 30 peserta didik dan yang tidak mencapai KKM sebanyak 25 peserta didik, rata-rata yang didapatkan secara keseluruhan dari hasil pretest kelas eksperimen yaitu 65,47 . Sedangkan pada kelas kontol yaitu VII B yang dapat mencapai KKM hanya berjumlah 3 orang dari 31 peserta didik dan yang tidak mencapai KKM sebanyak 28 peserta didik, rata-rata yang didapatkan dari nilai pretest secara keseluruhan dari kelas kontrol 57,68 .

Sedangkan pada tahap kedua yaitu pelaksanaan pembelajaran menggunakan model pembelajaran e-learning yang diberikan hanya kepada kelas eksperimen yaitu kelas VII A, sedangkan pada kelas kontrol yaitu kelas VII B pembelajaran hanya menggunakan model konvensional dengan ceramah. Setelah pemberian perlakuan tersebut pada tahap ketiga yaitu pelaksanaan posttest, dalam pelaksanaan posttest di kelas eksperimen yaitu kelas VII A mendapatkan hasil nilai tertinggi yaitu 100 . Peserta didik yang mendapatkan nilai tertinggi berjumlah 1 orang peserta didik, sedangkan nilai terendah adalah 68 yang diperoleh 4 orang peserta tetapi dalam pelaksanaan posttest keseluruhan peserta didik mengalami peningkatan hasil belajar. Sedangkan hasil nilai posttest di dalam kelas kontrol yaitu kelas VII B mendapat nilai tertinggi yaitu 88 sebanyak 1 orang peserta didik, dan nilai terendah yaitu 28 sebanyak 1 orang peserta, keseluruhan peserta didik yang menerima pembelajaran konvensional cenderung tidak mengalami peningkatan hasil belajar.

\section{Respon Positif Peserta Didik}

Setelah didapatkan penjumlahan secara keseluruhan dari data respon positif dari setiap peserta didik tersebut yang menunjukkan bahwa skor rata-rata kelas VIIA terdapat pada interval $71-85$,dapat dikategorikan bahwa peserta didik setuju apabila pembelajaran IPS menggunakan model pembelajaran e-learning terhadap kemampuan analisis peserta didik pada materi pelajaran lembaga sosial. Peserta didik merasa senang apabila pembelajaran tersebut menggunakan model pembelajaran e-learning, sehingga menjadikan peserta didik lebih fokus dalam mengikuti pembelajaran yang berlangsung.

Sedangkan pada ketrampilan siswa dapat diketahui bahwa rata-rata skor ketrampilan siswa saat pembelajaran dari ke 30 siswa adalah 70,53 dengan standar deviasinya sebesar 4,67, sehingga termasuk dalam kategori baik ketrampilan siswa saat pembelajaran. Adanya keterkaitan antara variabel $\mathrm{X}$ dan $\mathrm{Y}$ dimana dengan menggunakan model pembelajaran $e$ learning peserta didik merasa senang dan menyukai model pembelajaran yang inovatif dan interaktif yang kemudian berdampak kepada kemampuan analisis siswa yang membaik dan mudah memahami materi khususnya materi lembaga sosial. Berdasarkan hasil pembahasan di atas dapat disimpulkan bahwa penelitian mengenai efektivitas penerapan model pembelajaran e-learning terhadap kemampuan analisis peserta didik pada mata pelajaran IPS kleas VII SMP Islam Al Azhar 29 Semarang dapat dikatakan efektif. Hal tersebut dapat 
disimpulkan efektif karena 4 sub variabel telah terpenuhi dan tercapai.

\section{Kendala Dalam Penerapan Model Pembelajaran E-learning}

Kendala yang dihadapi oleh guru yaitu pak Arif Nur Hidayat, S.Pd. Gr sendiri yaitu lebih berfokus pada hardware yang tersedia, sistem LCD (Liquid Crystal Display) yang berbentuk digital menyulitkan laptop untuk masuk kedalam aplikasi kahoot. Sehingga dalam penerapan model pembelajaran e-learning pada mata pelajaran IPS membutuhkan waktu yang cukup lama untuk mencari LCD (Liquid Crystal Display) manual yang di hubungakan dengan menggunakan kabel. Kendala lainnya yaitu peserta didik menjadi riuh dan terlalu bersemangat saat memulai mengikuti quiz games sehingga keadaan peserta didik menjadi kurang kondusif. Kendala yang dialami pihak peserta didik sendiri yaitu terdapat beberapa peserta didik yang memiliki gejala rabun jauh sehingga tidak bisa melihat soal-soal quiz di layar proyektor, sehingga siswa yang merasa tidak jelas melihat layar proyektor maju kedepan kelas dan duduk dilantai sehingga pembelajaran yang berlangsung terkesan tidak rapih.

\section{KESIMPULAN}

Berdasarkan hasil penelitian dan pembahasan dapat ditentukan bahwa pembelajaran IPS menggunakn model pembelajaran e-learning terhadap kemampuan analisis peserta didik dilihat dari hasil belajar dapat dikatakan efektif melalui 4 variabel pada rumusan masalah kedua, sehingga dalam penelitian ini peneliti dapat menarik kesimpulan sebagai berikut: (1) Guru mampu melakukan langkah-langkah pembelajaran dengan menggunakan komposisi 50/50 dari alokasi waktu yang diberikan dimana 50\% untuk kegiatan pembelajaran tatap muka.

(2) Analisis kemampuan guru dalam mengelola pembelajaran sesuai dengan rencana pembelajaran mendapatkan skor 64 dengan kriteria kriteria tinggi. (3) Aktivitas belajar peserta didik dalam sub pembelajaran memiliki aktivitas tinggi 13\%, 63\% aktivitas siswa tergolong sedang, dan $23 \%$ aktivitas siswa tergolong rendah (4) Hasil belajar peserta didik jika dilihat dari nilai rata-rata nilai bahwa kelas VII A sebesar 65,47 dan kelas VII B sebesar 57,67 sedangkan nilai rata-rata posttest kelas VII A sebesar 78,73 dan kelas VII B sebesar 64, 67\% siswa kelas VII A yang tuntas KKM, hanya $13 \%$ siswa kelas VII B yang tuntas KKM sehingga dapat dikatakan efektif. (5) Dapat diketahui bahwa sebanyak 57\% siswa merespon baik terhadap pembelajaran dan sisanya $43 \%$ siswa merespon cukup terhadap pembelajaran. Sedangkan untuk variabel ketrampilan, dapat diketahui bahwa 70\% siswa memiliki ketrampilan baik dan sisanya $30 \%$ siswa memiliki ketrampilan yang cukup, hasil tersebut dapat dikatakan efektif. (6) Terdapat kendala yaitu pada hardware yang tersedia, kendala pada pihak peserta didik sendiri yaitu terdapat beberapa peserta didik yang memiliki gejala rabun jauh.

\section{DAFTAR PUSTAKA}

Ahmadi, Abu. 2009. Psikologi Umum. Jakarta: PT Rineka Cipta

Aziz Wahab, Abdul. 2009. Metode dan ModelModel Mengajar IPS. Bandung: Alfabeta

Daryanto. 2011. Media Pembelajaran. Bandung: PT. Sarana Tutorial Nurani Sejahtera

Daryanto, dan Muljo Rharjo. 2012. Model Pembelajaran Inovatif. Yogyakarta: Gava Media

Dewi, Cahya Kurnia. 2018.
Pengembangan Alat Evaluasi
Menggunakan Aplikasi Kahoot Pada Pembelajaran Matematika Kelas X. Lampung: UIN Raden Intan Lampung 
Dwiyogo, Wasis D. 2018. Pembelajaran Berbasis Blended learning. Depok: Rajawali Pres

Hidayati, dkk. 2008. Pengembangan Pendidikan IPS SD. Surakarta: Direktorat

Marini. 2014. Analisis Kemampuan Berfikir Analisis Peserta didik Dengan Gaya Belajar Tipe Investigatif Dalam Pemecahan Masalah Matematika. Jambi: Universitas Jambi

Purnomo, Arif, dkk. 2016. Model Pembelajaran Ilmu Pengetahuan Sosial (IPS) Pada Materi Kontroversi (Controversy Issues) Di Sekolah Menengah Pertama (SMP) Kota Semarang. Vol 33 . No 1.

Hal.13-25.
Solihatin, Entin dan Raharjo. 2007. Cooperative Learning: Analisis Model Pembelajaran IPS. Jakarta: Bumi Aksara

Sugiyono. 2008. Metode Penelitian Pendidikan (pendekatan kuantitatif, kualitatif, dan $R \& D)$. Jakarta: Alfabeta

Supardi. 2013. Sekolah Efektif: Konsep Dasar dan Praktiknya. Jakarta: PT Gramedia Widiasarana Indonesia

Warsita, Bambang. 2008. Teknologi Pembelajaran: Landasan dan Aplikasinya. Jakarta : Rineka

Wowo, Sunaryo Kuswana. 2014. Taksonomi Kognitif. Bandung: Remaja Rosdakarya 